\title{
Editorial
}

\section{Autoclaved bone graft usage revisited}

\author{
Jeanne A. Pawitan ${ }^{1,2}$ \\ ${ }^{1}$ Editor, Medical Journal of Indonesia, Jakarta, Indonesia \\ ${ }^{2}$ Department of Histology, Faculty of Medicine, Universitas Indonesia, Jakarta, Indonesia
}

In this issue, Asmara, et al recommend avoiding the use of bone graft for limb salvage, as their study on rat showed that autoclaved bone graft was inferior compared to non-autoclaved bonegraft (control). Autoclaved bone autograft is initially thought to be an economical choice compared to prosthesis, may not cause disease transmission and rejection problems, and does not challenge socioreligional beliefs. The reason of the inferiority of autoclaved bone graft are due to some reasons, including denaturation of collagen into gelatin, mineral degeneration, inactivation of bone morphogenetic protein 2 (BMP-2), vascular ischemia, and damage of bone structure in autoclave temperature, which lead to bone resorption and minimal bone formation, and finally failure of bone healing. High temperature are intended to eradicate malignant cells in bone and soft tissue sarcoma, thus the autoclaved bone can be reimplanted for limb salvage. ${ }^{1}$ High temperature also destruct the bone marrow, in addition to the various reasons already discussed in the study.

Bone marrow is rich in various kinds of stem cells, the majority are hematopoetic stem cells. in addition, bone marrow also contains mesenchymal stem cells that can differentiate into chondrogenic and osteogenic lineage, and other types of cells of mesenchymal origin, ${ }^{2}$ which play a role in bone healing.

In bone repair, there is cartilage callus formation where chondrogenic cells play a crucial role, followed by the role of osteogenic cells that are involved in bone formation that will replace the cartilage callus. ${ }^{3}$ Therefore, destruction of bone marrow that contains mesenchymal stem cells will substantially impair bone formation and repair, which is crucial for limb salvage.

For the purpose of limb salvage in patients with a bone malignancy, eradication of malignant cells from autologous bone graft can be achieved by various methods other than autoclaving, such as by irradiation, freezing, and pasteurizing. For the purpose of bone autograft, irradiation at $50 \mathrm{~Gy}$ showed that irradiated bone was biomechanically inferior compared to normal bone. ${ }^{4}$ Irradiation need a radiation facility, which is not always available in every hospital, and the need to transport to a remote facility causes an extension in sugery time. Moreover, irradiation at 50 Gy may not kill the malignant cells, as such a dose is also use to irradiate cells to be used as feeder layer in cell culture. A study used $6000 \mathrm{rad}$ (60 Gy) irradiated human dermal fibroblasts as feeder layer for keratinocyte culture. ${ }^{5}$ A feeder layer is composed of living cells that loose their mitotic capacity. Therefore, bone irradiation for the purpose of bone autograft for limb salvage may contain living malignant cells, though devoid of proliferation potential.

Exposure to freezing temperature in liquid nitrogen may kill the malignant cells, as freezing causes the formation of ice crystals inside the cell, which kill the cell. Liquid nitrogen freezing is a simple procedure, do not require special equipment, economical, and was shown to eradicate osteasarcoma cells. Moreover, frozen bone showed adequate biomechanical properties, and maintenence of osteoinductive and osteoconductive properties. Therefore, liquid nitrogen freezing is suitable for bone autograft in limb salvage in bone malignancy cases. ${ }^{6}$

Pasteurizing uses heat to eradicate the malignant cells, but at much lower temperature compared to autoclaving. Adequate heat treatment may lead to tumor destruction. Several studies showed that heat treatment at $44^{\circ} \mathrm{C}$ for 30 minutes, or diathermy heating using a radiofrequency of $13.56 \mathrm{MHz}$ caused tumor destruction, with minimal damage in surrounding normal tissues. Recently, pasteurization at $60-65^{\circ} \mathrm{C}$ for 40 minutes in a water bath eradicated malignant cells, which was shown by failure to grow in culture and lack of clonogenicity. ${ }^{4}$ Further, 
bone structure is preserved after pasteurization, and use of pasteurized bone graft showed less negative effect on bone healing compared to autoclaved bone graft. This fact might be due other characteristics of pasteurized bone, such as sparing of osteoinductive growth factors in pasteurization compared to autoclaving. ${ }^{7}$

Therefore, pasteurization or liquid nitrogen freezing are superior compared to autoclaved bone autograft for limb salvage in bone malignancy.

\section{References}

1. Asmara AAGY, Kamal AF, Siregar NC, Prasetyo M. Effect of autoclave devitalization to autograft incorporation and bone morphogenetic protein of tibia of Rattus novergicus. Med J Indones. 2014;23:74-8.

2. Dominici M, Le Blanc K, Mueller I, Cortenbach IS, Marini FC, Krause DS, et al. Minimal criteria for defining multipotent mesenchymal stromal cells. The International
Society for Cellular Therapy position statement. Cytotherapy 2006;8(4):315-7.

3. Kuryszko J, Kuropka P, Jedrzejowska I. Distraction osteogenesis and fracture healing. Differences and similarities. Acta of Bioengineering and Biomechanics 2000;2:83-8.

4. Kode J, Taur P, Gulia A, Jambhekar N, Agarwal M, Puri A. Pasteurization of bone for tumour eradication prior to reimplantation - An in vitro \& pre-clinical efficacy study. Indian J Med Res. 2014;139:585-97.

5. Bisson F, Rochefort E, Lavoie A, Larouche D, Zaniolo $\mathrm{K}$, Simard-Bisson $\mathrm{C}$, et al. Irradiated human dermal fibroblasts are as efficient as mouse fibroblasts as a feeder layer to improve human epidermal cell culture lifespan. Int J Mol Sci. 2013, 14, 4684-704.

6. Tsuchiya H, Nishida H, Srisawat P, Shirai T, Hayashi K, Takeuchi A, Yamamoto N, Tomita K. Pedicle frozen autograft reconstruction in malignant bone tumors. J Orthop Sci. 2010;15:340-9.

7. Vural R, Akesen B, Karakayali M, Yalcinkaya U, Aydinli U. The comparison of the negative effect of autoclaving and pasteurization on bone healing. Acta Orthop Traumatol Turc. 2010;44:322-327.

pISSN: 0853-1773 • eISSN: 2252-8083 • http://dx.doi.org/10.13181/mji.v23i2.990 • Med J Indones. 2014;23:63-4 Correspondence author: Jeanne A. Pawitan, jeanneadiwip@gmail.com

Copyright@ 2014 Author. This is an open access article distributed under the terms of the Creative Commons Attribution-NonCommercial-ShareAlike 4.0 International License (http://creativecommons.org/licenses/by-nc-sa/4.0/), which permits unrestricted non-commercial use, distribution, and reproduction in any medium, provided the original author and source are properly cited. 